\title{
Educational institutions negotiating democracy and social justice: The (im)balance of power and accountability
}

\author{
Paul Carr (Youngstown State University) \\ Gina Thésée (Université du Québec à Montréal)
}

\begin{abstract}
Democracy and education are considered to be mutually reinforcing, yet it is unclear how democracy is achieved in/through education. At a time when educational systems and governments rhetorically advocate for greater accountability for academic achievement, there seems to be less emphasis placed on the area of social justice for students. The capacity of the institutional culture of an entire educational system of a jurisdiction (the provincial/state level, school boards and schools) to support and achieve a high level of critical democracy has not been the focus of extensive research. For the purposes of this paper, democratic education is considered to be an amalgam of concepts, including how decisions are made, what those decisions are, and the effect of those decisions, covering both student outcomes and the institutional culture, with a particular emphasis on social justice. The paper argues for a more rigorous and balanced approach to conceptualizing democracy in education, thus the need to interrogate conceptions of power relations and accountability, and proposes a framework for democratic education.
\end{abstract}

\begin{abstract}
Résumé
On considère que la démocratie et l'éducation se renforcent mutuellement, mais ce n'est pas souvent clair, comment atteindre la démocratie à l'aide de, ou par l'éducation. Au temps où les systèmes d'éducation et les gouvernements prônent avec éloquence une responsabilité plus grande pour l'accomplissement académique, l'emphase se fait beaucoup moindre sur le domaine de la justice sociale pour les élèves. La capacité de la culture institutionnelle de tout système d'éducation qui relève d'une juridiction quelconque (au niveau provincial, ou d'un conseil scolaire, ou d'une école) pour soutenir et achever un niveau élevé de la démocratie critique ne fait pas encore le point d'extensives recherches. Pour le but de cet article, les auteurs considèrent l'éducation démocratique comme une amalgame de concepts qui incluent: comment les décisions se prennent, quelles sont ces décisions, et les effets de ces décisions à la fois sur l'accomplissement des élèves et sur la culture des institutions, en accordant une importance particulière à la justice sociale. L'article soutient une approche plus rigoureuse et mieux balancée pour conceptualiser la démocratie en éducation. De là s'ensuit le besoin d'interroger les conceptions sur l'interrelation des pouvoirs et les responsabilités. Il propose aussi une structure pour l'éducation de la démocratie.
\end{abstract}




\section{Introduction}

The rationale for the examination into democracy in education is found in the visible gap between sweeping policy-statements about the importance and centrality of accountability for everything from spending to academic achievement, on the one hand, and the reality of systemic racism (Dei, 1996), the marginalization of minority groups (Carr, 1999), White power and privilege (Feagin, Vera and Batur, 2001), and a notable schism in how power is structured in education (McLaren, 2007), on the other. While a philosophical understanding and diagnosis of inequities and difference in education is essential (Applebaum, 2005), we would also argue that equally important is the insistence on the applied, operational components in educational institutions. These could include an equitable allocation of resources, equitable outcomes for all students, inclusion, representation, democratic decision making processes, responsive programming, appropriate assessment methods, and a critical and open evaluation system at the student, teacher, school, board and provincial/state levels, all of which speaks to what could be considered as a conception of "democratic education".

While some have written extensively on the severe shortcomings of education as a vehicle for social cohesion, merit-based advancement and equity (McLaren, 2007), arguing strenuously that the political and economic organization of society is more germane than the schooling experience to explain social mobility and disenfranchisement (Bowles and Gintis, 2001), there is also widespread acceptance of the notion that education has a considerable role to play in creating the conditions for social change (Vincent, 2003). The degree to which this may take place in a liberal-democratic, capitalist-oriented political system has been a subject of debate for some time. In sum, it is our view that democracy and the pivotal descriptor therein, accountability, are, conceptually, and need to be, in reality, intimately inter-twined, and, further, that social justice must involve, in addition to the legislative and community empowerment pieces, an institutional change process in/with/through those very institutions charged with cultivating, shaping and forming young people through to adulthood. Accountability is not used here to symbolize the traditional right-wing "Total Quality Management" mantra of maximizing profits; rather, it is used as a lynchpin to question, critique and advance notions of democracy and equity at several levels in complex institutions (Fullan, 2005; Leithwood, 2001).

As in many other fields, the terminology in the area of democratic education is not easily reconcilable. Levin (1994) has noted that "democracy" and "education" are value-laden terms. Different contexts, jurisdictions, researchers and trends underscore the vacillating labeling of the nomenclature. Vincent (2003) encapsulates the critical notion of bringing together social justice and identity, which are key variables to understanding democracy. For the purposes of this paper, democratic education is meant to be understood as a crystallization and re- 
conceptualization of inter-related concepts, which address how decisions in education are made, what those decisions are, and the effect of those decisions, especially in relation to social justice, citizenship, and critical engagement in democracy. More than simply ascertaining whether or not a policy on democratic development exists, we are particularly concerned with the political ideology, demonstrable impact and implications of any such policy for teachers, students, parents and other educational partners. In sum, we are interested in the content of democratic education (the curriculum, extra-curricular and civic engagement activities) as well as, significantly, the decision making process underpinning, and infused in, the institution, including, in particular, issues of equity and accountability, both within the classroom and at the institutional level. After critiquing the state of democracy in education, the paper culminates with a proposal for a framework for democratic education, with a focus on accountability and social justice.

\section{Conceptualizing Democracy}

There are numerous definitions of, and for, democracy, all underpinned by some ideological and philosophical predisposition. A simple Google search under the word "democracy" reveals more than twenty-five million links. Official government documents will most assuredly point to human rights and a host of "democratic" protections and freedoms, inferring that, one can assume, comparatively speaking, democracy is not as widespread or as pure in all contexts (Schugeransky, 2003). Democracy involves people-- who are, ultimately, citizens- and the institutions and conventions that govern them (Portelli and Solomon, 2001).

There is no doubt that some are better positioned than others to influence power, decision-making and policy, and, therefore, to define the formal understanding and representation of democracy (Portelli \& Solomon, 2001). Thus, it is critical to investigate and to understand the backgrounds, origins and experiences of the plurality of people who constitute the citizenry (Wilkinson and Hébert, 1999: Kymlicka, 1995). Henry and Tator (2005) have written of the notion of "democratic racism" to encapsulate the pervasiveness of exclusion and discrimination in Canadian society, which effectively diminishes the value of democracy. Legal guarantees for a "just" society are not reflected in the day-today realities and experiences of some minority groups, thus exposing the lack of state commitment toward the eradication of strongly entrenched power imbalances (Henry \& Tator, 2000).

Others have openly conjectured about the power and privilege of being White in a society that places a premium on race (Dei, Karumanchery, \& Karumanchery-Luik, 2004; Feagin, Vera, \& Batur, 2001). Without understanding the pervasiveness and political impact of Whiteness on the broad swath of our 
socio-economic and legislative institutions, it would be impossible to disentangle the true worth of democracy. Similarly, Applebaum (2005) has emphasized how Whiteness can obscure the social justice debate:

When moral responsibility is primarily dependent upon fault, causality and accountability, on the one hand, and on assumptions that one can perceive oneself and others as standing outside of social, economic and historical contingencies, on the other, systemic oppression may be more difficult to discern and denials of complicity may be encouraged. (p. 288) Similarly, at the educational level, the issue of teachers being predominantly from White, middle-class backgrounds, whose lived experiences do not often mesh with highly diverse student bodies, has been flagged as being problematic in relation to the achievement of social justice objectives (Sleeter, 2000; Solomon et al., 2005). Lastly, the Council of Europe (2005) also views democratic citizenship, at least philosophically, in an integrated fashion:

Knowing one's rights as a citizen, and how to exercise them, means more than going to the polling station. It entails...helping to integrate vulnerable groups and minorities into the community... (and) inculcating more widespread awareness of the principles of socially responsible consumerism and of all forms of behaviour and measures that perpetuate and strengthen mechanisms for the direct and indirect practice of democracy. (Downloaded from the Council website)

In sum, the linkage between democracy and social justice is clear, and, importantly, for the concept of accountability, a key indicator of democratic achievement, to be meaningful it must reconcile the inequitable power relations shaping the decision making process (Vincent, 2003; Westheimer \& Kahne, 2004).

\section{Contextualizing Democracy in Education}

Arguably, public education represents society's best chance at substantive social change. Public education is intended to reinforce democracy (Westheimer \& Kahne, 2004). Levin (1994:20) points out that "Education has to do with the creation of situations in which there is debate and discussion, in which people learn about what to do, and in which decisions are subject to challenge, and to the requirement to give good reasons, taking into account others as full, human persons who deserve respect". In analyzing the problematic of citizenship within the Canadian context, Hébert (2002) emphasizes the connection between democracy and a vibrant collective identity and social cohesion, which speaks to the social justice agenda and the need to confront the marginalization of minorities.

As governments struggle to find the right balance, to respond to societal needs, and to strive for social harmony through education, it is noteworthy that 
few studies have been undertaken on the conceptualization of policy frameworks aiming to (re-)structure, oversee and promote democracy and citizenship in education, especially in relation to the key component of social justice. Despite the abundant rhetoric on building a system that is open, inclusive, democratic, and centered on the needs of all students, little is known about the (explicit and implicit) policies, programs and practices of entire educational systems (Departments or Ministries of Education, school boards and schools) in relation to democratic education. Torney-Purta et al. (2001), in their extensive study of civic education in 28 countries, highlight the problematic of trying to find the right language and concepts to appreciably make valid comparisons and to understand the state of democracy in diverse societies.

The changing political landscape in Western countries, although firmly anchored in a free-market political and economic system, complicates the conceptualization and delivery of democratic education. In Ontario, for example, the change of governments-- from a left-leaning regime (the New Democratic Party, 1990-1995) to a right-leaning government (the Progressive Conservative Party, 1995-2003), to a more centrist vision (the Liberal Party, elected in 2003)--, exemplifies the shift in ideas, policies and resources, and, with it, the challenge of governing, as well as shaping a sustainable vision and ideology for education. In particular, the transfer of power in 1995 has been considered a watershed moment in education, characterized by a radical "neo-conservative" schism in relation to (the elimination of) equity policies, the rapid realignment of governance structures, and (aggravated) relations with the educational sector (Corson, 2001; McCaskell, 2005; Rezai-Rashti, 2003). This period of change also included a "back to basics" pedagogical approach, funding cuts, the push for private and charter schools, school-business partnerships, the introduction and promotion of standardized testing for students, and teacher testing/assessment (McCaskell, 2005). The trends across Canada are not entirely different from the Ontario experience, although other jurisdictions may have moved more cautiously, consulted more, sought to maintain some form of an equity framework, and been less overtly ideological in their approach. In the United States, the sweeping and (supposedly) all-encompassing No Child Left Behind, with its focus on standards (Essex, 2006), has left many questioning the role and place of democracy and social justice in education. The notion, therefore, that education should and must support democracy has been increasingly noted (Osborn, 2003), especially when considering the waves of immigration rendering school classrooms increasingly more heterogeneous (Slote Morris, John \& Halpern, 2000; Hébert, 2002).

A number of factors underpin the rationale for democratic education. In the Canadian context, as is the case elsewhere, there is the obvious (democratic) issue of low voter participation in elections, particularly among youth, with only $22 \%$ of $18-20$ year-olds voting in the 2004 federal election, compared with $80 \%$ 
for the 58-67 age-group (Cook 2004:1). Patterson (2003) has documented a vast array of reasons for which Americans have opted to not participate in elections in his book The Vanishing Voter. The widely-held belief that elections are inextricably tied to democracy is illuminating when variables such as money, participation rates, identity, the role of the media, polling, myriad systemic barriers preventing and dissuading people from voting, and the actual rationale for supporting one candidate/party over another are taken into consideration. Some have even argued that no "democratically" elected government ever has a clear mandate, in large part because of the myriad reasons for which electors choose to vote (Clarke et al., 1984; Patterson, 2003). The debate over governments, elections and democracy necessarily involves teaching, learning and the education process to prepare students and citizens to become engaged in democracy.

Being able to study and critique electoral, representative and participatory democracy should be an integral piece to a democratic education curriculum. It is equally important to understand how educators and decisionmakers internalize their notion of democracy when faced with the bold reality that, for example: Canada ranks $109^{\text {th }}$ in the world in voter turnout; only $20 \%$ of parliamentarians are women (placing it $36^{\text {th }}$ internationally), and even a smaller percentage represent racial minorities; and the notion of every citizen having an equal vote is not reflected in the actual distribution of seats at the regional level (Fair Vote Canada, 2005). Within the US context, does the average citizen make a clear distinction between Republicans and Democrats, understanding how their interests are enhanced by voting for one party or the other (Patterson, 2003)? Ultimately, formal electoral and party politics constitute only a small slice of the democracy pie, often obfuscating real issues by emphasizing the potential for change with the election of a new government. Ironically, educators often point to elections as being the defining feature of democracy, de-emphasizing or omitting critical educational, cultural and political engagement (Carr, 2006).

Education, especially in the area of civics and social studies, has also been linked to youth engagement in the community as well as in electoral politics (Mellor, 2004; Osborn, 2001). Questions have been raised about the level of interest that youth have in formal politics, while, at the same time, some have found that young people are not necessarily disengaged from social issues (Slote Morris, John and Halpern, 2003). However, not all teachers are ably prepared and engaged to teach social issues (Cook, 2004). One Australian report (Mellor, 2004) suggested that only $1 \%$ of teachers had received the appropriate training to teach progressive citizenship education. Ultimately, "the consensus regarding critical thinking generally vanishes when the possibility arises that students will articulate conclusions that differ from mainstream or parental values," (Westheimer and Kahne, 2002:99), which serves as a cautionary tale for 
decisionmakers and educators interested in "doing" democracy but wanting to structure the outcome at the same time. The notion of teachers as political agents is often at odds with the desire for them to shape and model (positive) values (McLaren, 2007).

There is a conceptual and ideological basis to the drafting of documents, policies and activities (Speer \& Bradford, 2002), which serves as a concrete platform for interaction between teachers and students. What to teach, how, when, how much, and to whom, combined with the issue of process and results, is extremely critical for democracy to flourish. Westheimer (2004) questions the orientation of civic education in the post-September 11 US, where he underscores that "Dissent, rather than being an essential component of democratic deliberation, is seen as a threat to patriotism. Indeed, 'politics', in this view, is something unseemly and best left to mud-slinging candidates for public office: being political is tantamount to devaluing the public good for personal or party gains" (p.232). Lind (2005) has postulated that students need to develop authentic moral and democratic competencies for them to be able to meaningfully grow and participate in a democratic society.

A natural ally to the formal curriculum is the area of service-learning, sometimes referred to as community service or civic engagement. Westheimer and Kahne (2002) have emphasized that service-learning is political, and that charity tends to be the most politically acceptable form of involving students in the community, rather than social justice work. Westheimer (2003) highlights that "Volunteerism and kindness can be put forward as ways of avoiding politics and policy. In terms of democratic citizenship, these programs may be limited" (p.19). Schugurensky (2003) points out that civic involvement improves the community, and can help reduce problems and conflicts as individualism is decreased. It is clear that, as Kymlicka (1995) has pointed out, we are now in a world of de facto multicultural citizenship. In sum, in terms of democratic education based on social justice and citizenship, there is a strong and implicit connection between the curriculum, service-learning and community involvement, and the more it is made explicit the more likely it will be effective (Osborn, 2001).

To speak of education in the contemporary context without addressing issues of diversity and equity is problematic (Carr, 1999; Dei, 1996; Henry \& Tator, 2005). Any reforms, evaluations, research or initiatives emanating from legitimate sources must meet the challenge of equitable outcomes for all students (Fullan, 2005; Leithwood, 2001; Leithwood \& Riehl, 2003). This may not translate into entirely equal outcomes but it would infer taking into consideration responsibility for the development and implementation of policies, programs and initiatives, including establishing standards and targets, and collecting data and undertaking research. Without data and research, how would one know if there is equity, and democracy, in education? 
Young and Levin (1999) highlight the importance of ideology and national political tradition in studying educational reform in a comparative setting, thus reinforcing the notion that politics cannot be disconnected from the (political) decision making process in education (Wolf \& Macedo, 2004). Elected political leaders are able to establish the tone and policy for the educational sector. Their power is immense when one considers that they have the ability to define the language-- to not speak of the positioning and articulation of polices and resources-- used in the educational sector. If they decide that the word "racism" is no longer to be used, then the institutional response throughout the system will resonate in a number of concrete actions, which may explicitly avoid "doing" social justice (Carr, forthcoming).

Being able to address race-related and/or social justice issues would become increasingly problematic, in this case, and the access-points for consideration of such matters would be severely limited (Corson, 2001; RezaiRashti, 2003). As prioirities shift, strategic plans for school boards and schools would fall into line, avoiding antagonism with the senior policymaker in the jurisdiction. Therefore, being able to introduce progressive ideas, to garner and sustain support, to ensure effective implementation, and to deter massive upheaval and dissent is a problematic and contested domain in the (politico-)educational realm (Fullan, 2005; Levin, 1994). Ultimately, education about and for social justice overlaps with the notion of democratic education: arguably, one could not be taught without the other (Freire, 1973).

\section{Developing a Democratic Education Framework}

A conceptual framework for the development, implementation and evaluation of democratic education is necessary because of the clear lack of accountability for policies, funding, resources, activities and outcomes (Portelli \& Solomon, 2001). Moreover, the critical areas of citizenship and social justice continue to be highly contested, elusive and marginalized within the outcomes-based, standards agenda (Carr, forthcoming). Whereas accountability and transparency have become essential components to the educational reform agenda for the past decade for a host of indicators, no such comprehensive set of standards, guidelines and measures in relation to democratic education exists. Fullan (2005) has highlighted how important it is to establish targets, and to measure results in order to improve outcomes. Portelli and Solomon (2001) have highlighted the need for democracy in education to address, and be infused with, a critical social justice perspective. Of particular importance, in addition to all of the moral, legal, social, economic and political arguments for emphasizing social justice, a number of studies (Collaborative for Academic, Social and Emotional Learning, 2003) have demonstrated that a solid social justice focus in education will improve educational outcomes, the very purpose of the standards-based movement. 
A proposed framework for democratic education should include the requirement for the establishment of standards, measures and indicators for democratic education that speak to the true essence of democracy. Critical features of an accountability framework to address and buttress social justice, and to give it a similar stature to that accorded the general notion of "academic achievement", could include substantive content components, such as how strategic policy is developed, what characterizes the leadership, the content and, importantly, the relevance of the curriculum, the value of extra-curricular activities and servicelearning, with an analysis on the clear connection to teaching and learning, the depth and scope of community involvement, and the training of educators. Ultimately, we are interested in the nature of the institutional culture and school climate. We are not recommending tinkering with the margins but, rather, examining closely complex, dynamic and inter-woven issues, concerns and variables shaping the institutional culture in an integrated and holistic fashion. Over-lapping with the content areas would be functional criteria, including critical considerations such as inclusion, representation, decision making processes, communications, funding, data-collection and analysis, accountability mechanisms, and monitoring and review processes. The objective would be to rigorously account for decisions and outcomes with a particular view to ensuring that social justice is considered integral, not just an add-on or supplementary issue to deal with when inequities are publicized.

Weaving together these core components of how education is developed, delivered and structured in the form of a matrix, with the same vigor, resources and commitment as has been exhibited for mainstream "accountability" for the education system and society, would force decisionmakers to acknowledge the needs of all groups in society. The evaluation of each of the components, along with the standards and targets established for each, would provide a road-map for further reflection, analysis and restructuring in order to render the educational system more democratic. It is worth reiterating that this framework is for the entire education system of a given jurisdiction, as there are innumerable connections and linkages between the highest and lowest levels representing the Department/Ministry of Education, school boards and the schools within the jurisdiction.

\section{Conclusion}

Democratic education is considered complex for several reasons: a) there is no consensus on the exact definition; b) the political nature of education encourages shifting visions; c) there is an insistence on short-term solutions in education as opposed to long-term planning and policy implementation; d) there is no entrenched culture of assessing entire education systems, in part because of the 
potential implications of exposing shortcomings; e) permitting a critique of the status quo would be threatening to conservative elements and elites; and f) there are structural issues which do not encourage the development and implementation of comprehensive conceptual models, especially when bone fide accountability is at issue. Fullan (2005) has characterized current education reforms as being in a state of disarray: "top-down versus bottom-up; short-term versus long-term results; centralization versus decentralization; informed prescription versus informed professional judgment; transactional versus transformative leadership; excellence versus equity. And how does one achieve large-scale reform, anyway: reform that is characterized by serious accountability and ownership?" (p.ix). A key foundation of democratic education lies in the area of true accountability but, according to Leithwood (2001), there are at least five reasons why most accountability policies are unsuccessful: (un)ethical considerations; the purpose intended by policymakers is often not achieved; they can distract students from learning; teachers can be deterred from doing their best teaching; and policymakers often misjudge implementation.

Ultimately, democratic education is multi-layered, problematic, involves numerous interests and stakeholders, and requires a strong sense of accountability for it to have more than symbolic currency. A democratic education framework could be a useful tool to involve diverse sectors, to determine resources, to plan activities, to report on gaps, needs and outcomes, and to bring under one umbrella the myriad issues required to infuse democracy throughout the system. Therefore, the reason for promoting a democratic education framework is four-fold: a) it may have a positive effect on democracy in society; b) it underpins human rights and social justice, and attempts to match rhetoric and laws with the reality at the grassroots level; c) the educational experience (in terms of academics and citizenship) may be greatly enhanced for all students; and d) educational systems may become more accountable, responsive and inclusive.

The development of such a conceptual model would assist in the evaluation of educational systems in order to provide a portrait of the degree to which the entire system is democratic, where there are gaps, and how it might best proceed to ensure greater democracy throughout. The process required to use such a conceptual model is extensive, and it would be critical to ensure that those charged with leading the review and design process are well respected, and representative of the various components of the education system. It is clear that an important part of creating a democratic education system involves encouraging, supporting and employing democratic decision making processes.

The development of a democratic education framework requires, and leads to, complementary research. First, it would be useful to test and validate the accountability mechanisms in any such model by undertaking comparative studies of diverse education systems, attempting to determine the degree of difficulty in 
using the framework, as well as the utility that it would provide decisionmakers and stakeholders in shaping, analyzing and improving their democratic education approaches, policies and programs. Second, given the emphasis on the importance of equity, research on how marginalized groups can democratize policy development and implementation in relation to democratic education, as well as the particular challenges they face in becoming involved in the decision making process and in seeking equitable results at all levels, would also be welcome. Third, the question of academic achievement, in light of citizenship/democratic education outcomes, should be addressed, particularly in relation to standardized testing, grading, graduation requirements and the curriculum. The concern here is to better understand how education systems actually demonstrate their commitment to developing the whole student, and to being democratic in all aspects of their operations. Therefore, it is clear that there needs to be a strong linkage between social studies (the curriculum) and civic engagement, and emphasis should also be placed on measuring the "democratic" attitudes, behaviours and performance of students.

Having a vision, a plan, the resources and the processes in place to facilitate inclusion, representation, social cohesion, improved student outcomes (at the academic, citizenship and social levels) among all students, as well as a strategy to combat institutional resistence under a democratic education framework, involves an arduous, long-term journey. It is understood that the purest form of democracy will never be achieved but that the process of striving for that objective will undoubtedly bode well for all those involved in the system. Challenging all levels of education to work together, to become more accountable, to ensure inclusivity and social justice, and to render decision making processes the servant of the greater good of society, will ultimately improve education and democracy. In sum, in a political world required to make and enforce political decisions about priorities in education, the enterprise of building a democratic education system cannot neglect political realities, nor the more critical matter of social justice and the public interest. Strong moral and ethical leadership must involve a critical understanding of, and engagement with, social justice. 


\section{References}

Alexander, G. C. (1999). Schools as communities: purveyors of democratic values and the cornerstones of a public philosophy, Systematic Practice and Action Research, 12(2), 183-193.

Applebaum, B. (2005). In the name of morality: moral responsibility, whiteness and social justice education, Journal of Moral Education, 34(3), 277-290.

Bowles, S. \& Gintis, H. (2001). Schooling in capitalist America revisited, Sociology of Education, 75(1), 1-18.

Carr, P. (1999). Transforming the institution, or institutionalizing the transformation? Racial diversity and anti-racism in education in Toronto, McGill Journal of Education, 34 (1), 49-77.

Carr, P. (2006). Democracy in the Classroom?, Academic Exchange Quarterly, 10(2).

Carr, P. (forthcoming). Educational Policy and the Social Justice Dilemma. In H. Claire \&

C. Holden (Eds.), Controversial Issues in Education. London: Trentham.

Clarke, H., Jenson, J., LeDuc, L. \& Pammett, J. (1984). Absent mandate: the politics of discontent in Canada. Toronto, Gage Publishing Limited.

Collaborative for Academic, Social and Emotional Learning (2003). Safe and sound: an educational leader's guide to evidence-based social and emotional learning (SEL) programs. Chicago: US Department of Education, Mid-Atlantic Regional Education Laboratory.

Cook, S. A. (2004). Learning to be a full Canadian citizen: youth, elections, and ignorance, Canadian Issues Magazine, September, 1-6.

Corson, D. (2001). Ontario students as a means to the government's end, Our Schools Our Selves, 10(4), 57-80.

Council of Europe. (2005). Education for democratic citizenship. Accessed on November 5, 2005, at http://www.coe.int/T/E/Com/Files/Themes/ECD/.

Dei, G. (1996). Antiracist education: theory and practice. Halifax: Fernwood.

Dei, G., Karumanchery, L. \& Karumanchery-Luik, N. (2004). Playing the race card: Exposing white power and privilege. New York: Peter Lang.

Essex, N. (2006). What every teacher should know about No Child Left Behind. Boston: Pearson.

Fair Vote Canada. (2005). Make every vote count: this is democracy?. Toronto: Fair Vote Canada.

Feagin, J., Vera, H. \& Batur, P. (2001). White racism. New York: Routledge.

Freire, P. (1973). Pedagogy of the Oppressed. New York: Continuum.

Fullan, M. (2005). Leadership and sustainability: system thinkers in action. Thousand Oaks, California: Corwin Press.

Henry, F. \& Tator, C. (2005). The colour of democracy: racism in Canadian society. Toronto: Nelson Thompson.

Hébert, Y. (2002). Citizenship in transformation in Canada. Toronto: University of Toronto Press.

Kymlicka, W. (1995). Multicultural citizenship. Oxford: Oxford University Press.

Leithwood, K. (2001). 5 Reasons why most accountability policies don't work (and what you can do about it), Orbit, 32(1), 1-5.

Leithwood, K. \& Riehl, C. (2003). What we know about successful school Leadership. Philadelphia: Laboratory for Student Success, Temple University. 
Levin, B. (1994). Democracy and education, students and schools. Paper presented the Under scrutiny again: what kind of secondary schools do we need? conference, Simon Fraser University, Vancouver, B.C..

Lind, G. (2005). Moral dilemma discussion revisited - the Konstanz method, European Journal of Psychology. Accessed on November 7, 2005, at http://www.ejop.org/archives/2005/02/moral_dilemma_d.html.

McCaskell, T. (2005). Race to equity: disrupting educational inéquality. Toronto: Between the Lines.

McLaren, P. (2003). Life in schools: an introduction to critical pedagogy in the foundations of education. Boston: Pearson Education, Inc..

Mellor, S. (2004). Solving some civics and citizenship education conundrums in Australia. Accessed on August 21, 2005, http://www.curriculum.edu.au/democracy/prof_dev/mellor.htm\#.

Osborn, K. (2001). Democracy, democratic citizenship and education. In J. Portelli \& P. Solomon (Eds.) The erosion of democracy in education: from critique to possibilities (pp. 29-61). Calgary: Detselig Enterprises Ltd..

Patterson, T. (2003). The vanishing voter: public involvement in an age of uncertainty. New York: Vintage Books.

Portelli, J. \& Solomon, P. (2001). The erosion of democracy in education: from critique to possibilities. Calgary: Detselig Enterprises Ltd..

Rezai-Rashti, G. (2003). Educational policy reform and its impact on equity work in Ontario - global challenges and local possibilities, Education Policy Analysis Archives, 11(51), 1-15.

Schugurensky, D. (2003). Civic participation - on active citizenship, social capital and public policy, Canadian Diversity, 2(1), 10-12.

Sleeter, C. (2000). Multicultural education, social positionality, and whiteness. In E. Manuel Duarte \& S. Smith (Eds.) Foundational perspectives in multicultural education (pp. 118-134). New York: Longman.

Speer Lemisko, L. \& Bradford, K. J. (2002). "All of us": searching for inclusive representations of Canadians in social studies curricula, Canadian Journal of Education, 27(4), E5-E12.

Slote Morris, Z., John, P. \& Halpern, D. (2000). How immigration is changing citizenship: a comparative view, Curriculum Journal, 11(1), 39-54.

Solomon, P., Portelli, J., Daniel, B.-J., \& Campbell, A. (2005). The discourse of denial: How White teacher candidates construct race, racism and "White privilege". Race Ethnicity and Education, 8(2) 147-169.

Torney-Purta, J., Lehmann, R., Oswald, H. and Schulz, W. (2001). Citizenship and Education in Twenty-Eight Countries: Civic Knowledge and Engagement at Age Fourteen. Amsterdam: International Association for the Evaluation of Educational Achievement.

Vincent, C. (2003) Social justice, education and identity. London: RoutledgeFalmer.

Westheimer, J. (2003). Citizenship education for a democratic society. Teach Magazine, April, 1-3.

Westheimer, J. (2004). Introduction - the politics of civic education. Political Science and Politics, XXXVII(2), 231-234.

Westheimer, J. \& Kahne, J. (2002). Education for action: preparing youth for participatory democracy, in: R. Hayduk \& K. Mattson (Eds) Democracy's movement: reforming the American political system for the 21 $1^{\text {st }}$ century (pp.91-107). Lanman, Maryland: Rowman and Littlefield. 
Westheimer, J. \& Kahne, J. (2004).What kind of citizen?: the politics of educating for democracy, American Educational Research Journal, 41(2), 237-269.

Wolf, P. \& Macedo, S. (2004). Educating citizens: international perspectives on civic values and school choice. Washington, D.C.: Brookings Institution Press.

Paul R. Carr is an Assistant Professor at Youngstown State University, where he teaches courses in the sociology of education, and undertakes research on democracy and social justice. He co-edited a book entitled The Great White North? Exploring Whiteness, Privilege and Identity in Education (Sense Publishers). He can be contacted at prcarr@ysu.edu .

Gina Thésée is an Assistant Professor at the Université du Québec à Montréal, where she teaches science education and pedagogy. Her research focuses on the epistemology of education and intercultural education. She is presently editing a book entitled Les faces cachées de la recherche interculturelle, which will be published L'Harmattan in late 2008. She can be contacted at thesee.gina@uqam.ca . 